\title{
Poppy Capsule Dependence
}

\author{
SELWYN M. SMITH， IAIN BURNSIDE
}

British Medical fournal, 1972, 1, 480-481

\section{Summary}

Nine poppy-head addicts were seen at a Birmingham hospital. Seven were Sikhs born in Jullundur and two were West Pakistanis. Most began their poppy-head addiction in their early 20 s, usually out of curiosity or to relieve the hangover effects of alcohol. Only two took opium in addition and one of these had taken cannabis, morphine, and heroin. They all drank several pints of beer a day and were heavy smokers. All had had little schooling and married young. Most of them were industrious foundry workers in good physical health. Withdrawal of poppy capsules failed in each case. The present situation whereby an addictive drug is readily imported and sold in local shops is questioned.

\section{Introduction}

Poppy capsules have long been used in India (Watt, 1891-6). There is an early reference to the Emperor indulging in "Kuknar," a beverage prepared from the poppy capsules, and there is evidence that the capsules were used in the preparation of soporofic drugs and stimulating and soothing beverages, long

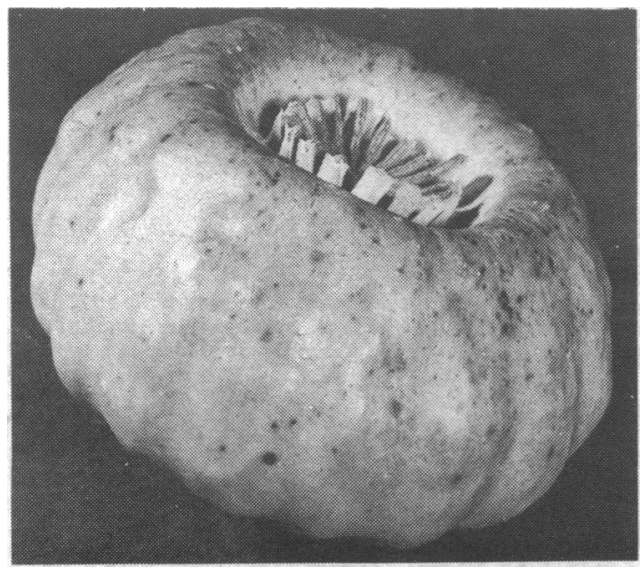

FIG. 1-Poppy capsule

before opium from the milky sap was known (Chopra and Chopra, 1965). Indian physicians appreciated their narcotic and soothing properties and they were prescribed for many ailments. Poppy capsules are still used in India as a household remedy to quieten teething children. In a study of habitual users of the capsules, $40 \%$ took the drug for minor conditions that it was believed to cure. They were not taken for serious disease (Chopra, 1930).

Poppy capsules are obtained from Papaver somniferum. The amount of opium alkaloids present varies with the type of poppy,

\footnotetext{
Department of Psychiatry, Clinical Research Block, University of Birmingham, Birmingham

SELWYN M. SMITH, M.B., B.S., D.P.M., Honorary Research Fellow

SELWYN M. SMITH, M.B., B.S., D.P.M., Honorary Research Fellow
(Recipient of Research Grant from the Endowment Fund, United Birmingham Hospitals)

Department of Psychology, All Saints' Hospital, Birmingham 18 IAIN BURNSIDE, M.SC., Clinical Psychologist
}

(Chopra and Ghosh, 1931); the principal compounds are morphine $(0 \cdot 1-0.3 \%)$, papaverine, codeine, narcotine, and thebaine (Todd, 1967), though some varieties of poppy capsule have a morphine content of $1 \%$ (J. W. Fairbairn, personal communication, 1971). A beverage is prepared by soaking the poppy capsules for four to five hours before use, and when soft they are broken into pieces. The alkaloids present in the capsule pass into the water and the whole mass is strained through a piece of cloth. The solution is then diluted or mixed with sugar to form the beverage. Eight to 10 average-sized capsules weigh about $60 \mathrm{~g}$ and the average intake is $10-20$ capsules a day, equivalent to $200-400 \mathrm{mg}$ of opium alkaloids.

The symptoms produced by poppy capsules are generally similar to those produced by opium but are milder and of shorter duration (Chopra and Chopra, 1965). Mentally the effects differ: a feeling of elation, exuberance, or well-being manifests itself in speech and gestures. There is loss of responsible control over the mental processes, but control of movements is not impaired as occurs with alcohol. The net result on the psychic areas is unrestrained imagination. In some it produces excitement, in others drowsiness or sleep. The physical effects are the same as observed in opium addicts (Chopra and Chopra, 1965).

This paper describes the clinical features of nine poppy capsule addicts; this form of addiction has largely passed unrecognized in Great Britain.

In the United Kingdom there have been only isolated reports of this form of addiction. Glatt and Hossain (1963) first described a case occurring in this country, and Paton (1963) commented on the ease of obtaining poppy capsules over the chemist's counter.

\section{Patients and Methods}

The salient features of the pattern of drug dependence in these nine patients are summarized in the Table. All except two were born in Jullundur, a city in North Punjab. All had had very little schooling and could not speak English, and, with one exception, all began farm labouring in early adolescence. All except one (Case 2) married early and have several children.

Reasons for beginning taking poppy capsules varied. The habit is apparently common among the male inhabitants of Jullundur, who regard it as quite natural. In general, poppy capsules were first taken to ease a hangover caused by alcohol, to improve concentration, or to produce a mild euphoria at social gatherings. One (Case 6) was introduced to the drug by friends to ease a phobia of the sea, which developed when he fell overboard. Most of them also drank moderate amounts of alcohol and smoked cigarettes. Some had also taken other narcotic drugs in the past.

After emigration to England several years ago all patients ceased the poppy capsule habit spontaneously, largely owing to ignorance of their ready availability. But on learning that poppy capsules could be obtained quite cheaply from local pharmacists, all reverted in a very short time to their original intake. It was not until pharmacists made a voluntary ban on stocking poppy capsules in 1969 that the patients were referred on account of withdrawal symptoms. Several of them had approached their general practitioners for opiates.

The addition of an interpreter to the hospital staff eased communication with these patients. All were then reassessed and it was noted that despite morphine substitution they had 
Salient Features of Pattern of Drug Dependence in Nine Cases

\begin{tabular}{|c|c|c|c|c|c|c|}
\hline $\begin{array}{l}\text { Case } \\
\text { No. }\end{array}$ & Age & $\begin{array}{l}\text { Age at } \\
\text { Starting } \\
\text { Poppy } \\
\text { Capsules }\end{array}$ & $\begin{array}{l}\text { No. of } \\
\text { Poppy } \\
\text { Capsules } \\
\text { Daily }\end{array}$ & $\begin{array}{l}\text { Reason for Initial } \\
\text { Commencement }\end{array}$ & $\begin{array}{l}\text { Other Types of } \\
\text { Drug Abuse }\end{array}$ & Liver Biopsy Specimen \\
\hline 1 & 37 & 21 & 15 & To ease alcoholic hangover & Alcohol & $\begin{array}{l}\text { Degenerative changes in the form of } \\
\text { variation in nuclear cell size and } \\
\text { accumulation of intracellular } \\
\text { lipofuscin }\end{array}$ \\
\hline 2 & 24 & 11 & 5 & $\begin{array}{l}\text { To improve energy and } \\
\text { concentration }\end{array}$ & $\begin{array}{l}\text { Opium, cannabis, heroin, morphine, } \\
\text { and alcohol taken previously }\end{array}$ & 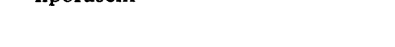 \\
\hline 3 & 31 & 17 & $25-30$ & To ease hangover & Alcohol & $\begin{array}{l}\text { Scanty diffuse mononuclear cell } \\
\text { infiltrate with swollen Kupffer } \\
\text { cells and degenerative changes in } \\
\text { the form of variation in nuclear } \\
\text { cell size and accumulation of } \\
\text { intracellular lipofuscin }\end{array}$ \\
\hline $\begin{array}{l}4 \\
5\end{array}$ & $\begin{array}{l}54 \\
41\end{array}$ & $\begin{array}{l}25 \\
12\end{array}$ & $\begin{array}{l}12 \\
36\end{array}$ & $\begin{array}{l}\text { Introduced at social gatherings } \\
\text { To improve energy and }\end{array}$ & $\begin{array}{l}\text { Alcohol } \\
\text { Opium and cannabis previously }\end{array}$ & \\
\hline 6 & 40 & 25 & 20 & $\begin{array}{l}\text { concentration } \\
\text { Introduced by friends to relieve } \\
\text { sea phobia }\end{array}$ & $\begin{array}{l}\text { taken } \\
\text { Alcohol }\end{array}$ & \\
\hline $\begin{array}{l}7 \\
8 \\
9\end{array}$ & $\begin{array}{l}43 \\
40 \\
50\end{array}$ & $\begin{array}{l}24 \\
15 \\
15\end{array}$ & $\begin{array}{c}12-20 \\
12 \\
13\end{array}$ & $\begin{array}{l}\text { Introduced at social gatherings } \\
\text { Introduced at social gatherings } \\
\text { Introduced at family gatherings }\end{array}$ & $\begin{array}{l}\text { Alcohol } \\
\text { Alcohol } \\
\text { Alcohol }\end{array}$ & $\begin{array}{l}\text { Degenerative changes in the form of } \\
\text { variation in nuclear cell size and } \\
\text { marked accumulation of intra- } \\
\text { cellular lipofuscin }\end{array}$ \\
\hline
\end{tabular}

reverted to buying poppy capsules at inflated prices. Three patients agreed to be admitted for withdrawal of poppy capsules and the rest were seen weekly as outpatients. Physical examination and laboratory investigations (full blood count, serum electrolytes, blood urea, urine, W.R., Kahn, and liver function tests, and chest $x$-ray examination) showed that most patients were in good physical health. Case 5 was short in stature $(5 \mathrm{ft}$; $15.2 \mathrm{~cm}$ ) and this was possibly due to chronic opiate intake. Only one (Case 9) was hypertensive (B.P. 170/120 mm Hg) and obese. A liver biopsy specimen was taken in three cases. This was justified because one patient (not in this series) had died from liver failure due to cirrhosis. They showed similar patterns of degenerative changes in the form of variation in nuclear cell size and accumulation of intracellular lipofuscin. The significance of this finding is not known. Mental state assessment, though necessarily limited in extent, showed no evidence of functional psychosis or organic brain impairment. Most patients were passive and vacillating and had extremely dependent personalities. Only one developed severe depression and this was after withdrawal of morphine.

The procedure adopted with each patient consisted in administering morphine tablets in a proportionate dose to previous poppy capsule intake. After several weeks methadone was introduced and morphine withdrawn.

Despite reduction of morphine with replacement by methadone and strong supportive measures, all patients failed to be completely withdrawn from morphine. All developed limb or cramp-like abdominal pains which were mostly relieved by injection of sterile water. Several patients demanded their discharge and have reverted to taking poppy capsules with small doses of morphine and are seen regularly as outpatients. Apart from Case 2 all have continued their employment in heavy industry.

The pursuit rotor, a measure of psychomotor skill, was administered before treatment and one month after withdrawal had been attempted. Auditory and visual reaction times were also noted. No changes were found in reaction time. A significant improvement in psychomotor skill was found only in the group which has shown significant reduction in drug intake, thus confirming the clinical impression of improvement.

Details of the psychological data will be published in a separate paper.

\section{Discussion}

Discussion with these patients revealed that the habit of taking poppy capsules is common among the Indian and Pakistani male community in the industrial Midlands. One noteworthy feature is that most ceased the habit spontaneously on arrival in England but on learning of the relative ease of obtaining poppy capsules reverted to their original custom quite quickly. The sale of poppy capsules was voluntarily banned by pharmacists in 1969 , an encouraging sign, but other stores in Birmingham quickly offered poppy capsules to the community, but at inflated prices. At present poppy capsules can be readily purchased. The capsule shown in Fig. 1 was purchased for $60 \mathrm{p}$ from a local florist.

Exact details concerning importation of poppy capsules into this country are difficult to obtain. The Home Office statistics show that $1,812 \mathrm{~kg}$ of poppy straw was imported in 1969 and $1,181 \mathrm{~kg}$ in 1970. Before 1969 the amount imported is not accurately known. This is a large amount and does not take into account the quantity illicitly received into this country. The situation at present exists whereby a drug of dependence has relative ease of access to the United Kingdom and is sold freely across the counters of local stores to the detriment of the local Asian population. Most of these patients were referred only for withdrawal when they found they could not afford the inflated prices of poppy capsules. The availability of poppy capsules in the community undoubtedly contributed to the failure of withdrawal.

Whether the degenerative changes observed in the liver biopsy specimens are due to chronic poppy capsule intake is speculative. However, unlike opium addicts, these patients were in good physical health. The condition is more difficult to treat than opium addiction probably because of the potentiating effect of the constituent alkaloids on one another. Although it has been suggested (Chopra and Chopra, 1965) that gradual withdrawal of capsules is the ideal method of treatment, the method of morphine substitution should not be discounted. It was our overall impression that these patients could have been withdrawn completely from poppy capsules if the latter had not been available so readily in the community.

We are grateful to Dr. J. Owens for allowing us access to patients under his care and to Professor W. H. Trethowan for his helpful advice and criticism in the preparation of this paper.

\section{References}

Chopra, R. N. (1930). Indian Medical Gazette, 65, 360

Chopra, R. N., and Chopra, I. C. (1965). Drug Addiction: With Special Reference to India. New Delhi, Council of Scientific and Industrial Research.

Chopra, R. N., and Ghosh, N. N. (1931). Indian Medical Research Memoirs, $19,415$.

Glatt, M. M., and Hossain, M. M. (1963). British Medical fournal, 2, 102. Paton, A. A. (1963). British Medical fournal, 2, 256. Todd, R. G. (editor) (1967). Martindale's Extra Pharmacopoeia, 25th edn.
London, Pharmaceutical Press.

Watt, G. (1891-6). Dictionary of the Economic Products of India. Calcutta. 